\title{
TISSUE SPECIFICITY IN EMBRYONIC AND ADULT \\ CYMATOGASTER AGGREGATA STUDIED BY SCALE TRANSPLANTATION
}

\author{
EDWARD L. TRIPLETT AND SUSANNE BARRYMORE \\ Department of Biological Sciences, University of California, Santa Barbara, \\ Goleta, California
}

The method of scale transplantation first used by Mori (1931) has proved to be of great value in studies on tissue specificity in fishes. Goodrich and Nichols (1933) and Hildemann (1956, 1957a, 1957b) have shown that, whereas autografts are always successful, homografts are invariably rejected by the host. These studies have established that the immune responses to homografts so profusely studied in mammals and birds are also observable in the goldfish (Carassius auratus).

The purpose of this investigation was to extend our knowledge of homograft reactions in fishes. Answers were sought to the following questions: (1) To what extent are adults of Cymatogaster aggregata (Gibbons) immunologically reactive toward scale homografts? (2) Are adults of this species capable of being sensitized to scale homografts (i.e., will secondary, tertiary, etc., grafts be more rapidly rejected than the primary graft)? (3) Does the reactivity of embryonic and immature $C$. aggregata toward scale homografts differ from that of the adults? (4) Assuming affirmative answers to the above questions, can a sensitized, pregnant female transfer this homograft sensitivity to intra-ovarian embryos?

\section{Materials And Methods}

Experimental animals

C. aggregata is a marine embiotocid fish which is distributed over the west coast of North America from southern Alaska through Baja California (Tarp, 1952). Like all embiotocids this species is viviparous, the young spending about five months in the hollow ovary and increasing in size from $0.25 \mathrm{~mm}$. (fertilized egg) to about $42 \mathrm{~mm}$. (newborn) in standard length (Eigenmann, 1889; Triplett, unpublished data). Animals used in this investigation were collected by angling from Goleta pier, Goleta, California.

\section{Methods}

The method of grafting was essentially similar to the one devised by Hildemann (1957b). Adult fish were anesthetized in tricaine methane sulfonate (MS 222), $1 / 5000$ dissolved in one per cent sodium chloride (MS 222 forms a white precipitate in sea water). Survival was greatest when the anesthetic was maintained at about $10^{\circ} \mathrm{C}$. Grafting was done simply by removing a scale from the ventral surface of the host and replacing it with a scale from the dorsal surface of the 
same fish or another fish. The transplant is easily distinguished since the scales of the dorsal surface of the body are heavily pigmented in contrast to those of the ventral surface which contain few or no melanophores. Grafted adults were maintained in aquaria provided with running sea water. They were fed ad libitum on pieces of mussel (Mytilus californianus).

Embryos were obtained by caesarian section using aseptic technique. They were then transferred to fingerbowls containing a modification (Triplett, unpublished data) of sterile White's medium (1954) and kept there until time was available for grafting. The embryos were anesthetized in $1 / 10,000$ MS 222 dissolved in the aforementioned solution. An incision was then made in the flank skin with iridectomy scissors. Into this was placed either a homograft consisting of a sterile, adult, trimmed scale, or an autograft consisting of a piece of pigmented skin. The scales of embryos, when present, are too small and lightly pigmented to be used as autografts. Adult scales were sterilized by immersion for one minute in $0.004 M$ mercuric chloride dissolved in modified White's medium and washed with sterile medium before grafting. The scale remained alive and apparently healthy after such treatment. Embryos were grafted and maintained at $17^{\circ} \mathrm{C}$. in a sterile culture chamber.

All host fishes, embryonic and adult, received a homograft and most fishes received an autograft. After it was established that autografts would survive and become healthy, some of the newborn in subsequent experiments were not given autografts in order to avoid this additional injury. In some cases reciprocal grafting of pairs of fishes was done. In others a single donor contributed scales to between three and eleven hosts.

The principle criterion for assaying the grafted scales was the condition of the scale melanophores. The melanophore is a single pigment cell of a radially dendritic pattern. The melanophores are usually somewhat separated from one another and readily visible under a dissecting microscope. These pigment cells contain many granules of melanin which respond to physiological changes to spread out into the cell's extremities, or to aggregate in the center of the cell. In a typical situation the melanophores of autografted scales, after an initial healing period, remained healthy and completely pigmented for an indefinite period of time. After a given time homograft melanophores began to undergo degenerative changes. The pigment aggregated as a black dot in the center of the melanophore and over a variable interval of time proceeded to fragment. The melanin granules were eventually phagocytized. In a few cases an inflammatory reaction similar to that described by Hildemann (1957b) and Goodrich and Nichols (1933) was observed. The time required for fragmentation of all the melanophores of the transplanted scale is here termed the reaction time.

\section{REsults}

\section{Adults}

The adults of this species, like many pelagic fishes, are difficult to maintain in a laboratory without running sea water. Therefore the temperature, of necessity, was that of the ocean at that particular time of the year. In order to measure the effect of temperature on the reactivity of animals toward homografts one series was performed between March and July (average temperature $=17^{\circ} \mathrm{C}$.), 
and another series was done between August and October (average temperature $=20^{\circ}$ C.).

In these series a single donor contributed scales to either three, four or five hosts. In all, 37 hosts and eight donors survived long enough to yield data. The hosts received as many as six successive grafts from the same donor, new grafts being placed-as soon as fragmentation of the melanophores of the previous graft was complete. As mentioned above all the autografts placed on hosts remained alive and healthy for the duration of the experiment (in some cases more than three months).

Both autografts and homografts underwent an initial healing phase during which time the melanophores that had been injured during the operation fragmented and were phagocytized. After the third post-operative day degenerating melanophores could no longer be found in the autografts, but progressive loss of melanophores continued in the homografts until all had disintegrated (reaction time). The reaction time for homografts is shown in Table I. Here it can be seen that the average reaction time for grafts at $17^{\circ} \mathrm{C}$. is 7.0 days. The reaction time of subsequent grafts decreased progressively until at the fourth grafting it averaged 3.5 days. Any further grafting was not effective in increasing homograft sensitivity.

It can also be seen in Table I, in confirmation of Hildemann's (1957b) findings, that increased temperature of the external medium has the effect of decreasing the reaction time. It was also observed that at the higher temperature the primary homograft has a more pronounced effect in producing sensitivity to subsequent grafts. These observations are paralleled by those of Cushing (1942) who found that the ability of fishes to produce antibody against injected erythrocytes or spermatozoa is influenced by temperature in such a way that circulating antibody appears sooner at higher than at lower temperatures.

Some evidence has been gathered which indicates (as might be expected) that fishes of this species, comprising a natural population of unknown interrelationships, bear some but not all scale tissue factors (antigens?) in common. Six fish of the series discussed above, which had received between four and six successive homografts, were each given a graft from a donor that had not previously been used. The average reaction time for this series was 5.6 days. The value for a primary graft would have been 7.0 days (average), and the value for a fifth, sixth or seventh set reaction would have been 3.5 days (average). Since the realized value is in between these two, the statement that each fish bears distinctive as well as common homograft factors seems justified. Medawar (1946) has made similar observations on rabbits.

\section{Significance of reaction time}

A small series of operations was performed in an effort to determine the relationship of the reaction time (melanophore disintegration time) to the complete destruction of the living tissue of the homograft. The method, first used by Hildemann (1957b), consisted of returning homografts to the donor after variable lengths of time. Failure of the graft to re-establish itself in the original donor indicated irreparable damage or death.

In this series five pairs of adult fish were used. Each donor contributed 10 
scales to its partner, and the grafted scales were returned to the donor at daily intervals. It was found in all five cases that scales returned to the host on or before the third day after the original grafting became re-established in the donor. Those returned on or after the fourth day did not survive. These data lack statistical

\section{TABLE I}

Reaction time in days for scale grafts to adult fish

Operations performed between March and July-Average water temperature $17^{\circ} \mathrm{C}$.

\begin{tabular}{|c|c|c|c|c|c|c|}
\hline Specimen no. & 1st graft & 2nd graft & 3rd graft & 4th graft & 5th graft & 6th graft \\
\hline $1-1$ & 11 & & & & & \\
\hline 2 & 7 & 7 & & & & \\
\hline 3 & 9 & 9 & 6 & 3 & 3 & 3 \\
\hline 4 & ? & 8 & 3 & 3 & 3 & 4 \\
\hline 5 & - & 4 & & & & \\
\hline $2-1$ & 9 & 11 & & & & \\
\hline 2 & 11 & 11 & & & & \\
\hline 3 & 11 & 11 & & & & \\
\hline 4 & 11 & 9 & & & & \\
\hline 5 & 3 & 10 & 4 & 4 & 3 & \\
\hline $3-1$ & 7 & 9 & & & & \\
\hline 2 & 6 & & & & & \\
\hline 3 & 6 & 6 & 4 & 3 & & \\
\hline 4 & 6 & 5 & 6 & 5 & & \\
\hline 5 & 9 & 4 & & & & \\
\hline $4-1$ & 11 & & & & & \\
\hline 2 & 6 & 5 & & & & \\
\hline 3 & 11 & 6 & 3 & 3 & 4 & \\
\hline 4 & 11 & 5 & 6 & 3 & 4 & 3 \\
\hline 5 & 11 & 5 & 6 & 4 & 4 & 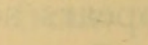 \\
\hline $5-1$ & 6 & 7 & 4 & & 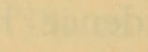 & \\
\hline 2 & 7 & 7 & & & & \\
\hline 3 & 6 & 7 & 3 & & & \\
\hline 4 & 6 & 8 & 4 & & & \\
\hline 5 & 0 & 5 & 5 & & & \\
\hline Average & 7.0 & 7.2 & 4.5 & 3.5 & 3.5 & 3.3 \\
\hline
\end{tabular}

Operations performed between August and October-Average water temperature $20^{\circ} \mathrm{C}$.

\begin{tabular}{r|r|r|r|r|}
\hline $1 \mathrm{~B}-1$ & 5 & & \\
2 & 5 & 3 & \\
3 & 5 & 3 & \\
4 & 7 & 3 & \\
$2 \mathrm{~B}-1$ & 5 & 3 & \\
2 & 7 & & \\
3 & 5 & 3 & \\
4 & 5 & 3 & \\
5 & 7 & 3 & \\
$4 \mathrm{~B}-1$ & 7 & & \\
2 & 7 & 5.0 & & \\
3 & 5 & & \\
\hline Average & 5.8 & & \\
\hline
\end{tabular}


force but suggest that homografts are no longer viable in a suitable environment several days before the reaction time ( 7.0 days at this temperature). It is felt, however, that the reaction time as used in the various experiments reported here is valid since all other data indicate that it is a function of host homograft sensitivity.

\section{Embryos}

Two series of experiments were done on intra-ovarian embryos. The hosts of the first series consisted of six siblings averaging $29 \mathrm{~mm}$. standard length, and the hosts of the second series consisted of 11 siblings averaging $19 \mathrm{~mm}$. standard length. The hosts in each series received homografts from a single adult, the operation and postoperative care being done in the manner described above.

Since the grafts had to be examined every day, and since the medium was rich in organic materials some difficulty was experienced in maintaining asepsis. In the first series, four animals lived 16 days, one lived 20 days and one lived 24 days. In the second series eight animals lived 20 days, and three lived 30 days.

An initial healing period lasted between three and five days. During this time damaged melanophores of both autografts and homografts were phagocytized. After this time both autografts and homografts remained alive and in excellent condition as long as the host lived. Since some of the embryos lived as long as 30 days there is a strong indication that intra-ovarian animals are incapable of eliciting the homograft reaction.

\section{Immature fishes}

The animals used in this series were divided into two groups on the basis of their parturition age. There survived in the first group 11 animals grafted one to three days after birth, and in the second group seven fishes grafted 15 days after birth. Some, but not all animals received an autograft consisting of a $0.25-\mathrm{mm}$. piece of skin, and all received a scale homograft from an adult fish. Each donor contributed to between three and seven hosts. All animals in this series were cultured at approximately $17^{\circ} \mathrm{C}$. in running sea water.

The autografts remained alive for the duration of the experiment. The homografts were without exception broken down in a manner similar to that described for the adult host homografts. It can be seen in the first two columns of Table II that the reaction time for homografts is approximately in inverse proportion to the age of the fish. The average reaction time for one- to three-day fishes is 13.2 days, whereas that for 15-day fishes is 9.7 days (that for adults is 7.0 days at the same temperature).

\section{Embryos from sensitized parents}

These experiments were performed in an effort to discover whether or not induced homograft sensitivity in parent fishes could be transferred to intra-ovarian embryos. A total of 11 pregnant females was sensitized. Ten were given a single scale homograft and one was given three successive homografts. The young were born from 10 to 30 days after the parent had received the last graft. The newborn animals each received a scale homograft one to three days after birth 
TABLE II

\begin{tabular}{|c|c|c|c|c|c|c|c|}
\hline \multirow{2}{*}{\multicolumn{2}{|c|}{$\begin{array}{c}\text { Host aged 1-3 days } \\
\text { Post-partum. } \\
\text { Parent not sensitized. }\end{array}$}} & \multirow{2}{*}{\multicolumn{2}{|c|}{$\begin{array}{c}\text { Host aged } 15 \text { days } \\
\begin{array}{c}\text { Post-partum. } \\
\text { Parent not sensitized. }\end{array}\end{array}$}} & \multicolumn{2}{|c|}{ Host aged $1-3$ days } & \multicolumn{2}{|c|}{ Host aged $1-3$ days } \\
\hline & & & & \multicolumn{2}{|c|}{$\begin{array}{l}\text { Post-partum. Parent given } \\
1 \text { or } 2 \text { successive homografts. }\end{array}$} & \multicolumn{2}{|c|}{$\begin{array}{l}\text { Post-partum. Parent giver } \\
3 \text { successive homografts. }\end{array}$} \\
\hline $\begin{array}{l}\text { Specimen } \\
\text { no. }\end{array}$ & $\begin{array}{l}\text { Reaction } \\
\text { time }\end{array}$ & $\begin{array}{l}\text { Specimen } \\
\text { no. }\end{array}$ & $\begin{array}{c}\text { Reaction } \\
\text { time }\end{array}$ & $\begin{array}{l}\text { Specimen } \\
\text { no. }\end{array}$ & $\begin{array}{l}\text { Reaction } \\
\text { time }\end{array}$ & $\begin{array}{l}\text { Specimen } \\
\text { no. }\end{array}$ & $\begin{array}{l}\text { Reaction } \\
\text { time }\end{array}$ \\
\hline $\begin{array}{r}\text { S-6-59-1a } \\
1 \mathrm{~b} \\
1 \mathrm{c} \\
\mathrm{S}-6-59-2 \\
3 \\
4 \\
6 \mathrm{a} \\
6 \mathrm{~b} \\
6 \mathrm{c} \\
6 \mathrm{~d} \\
6 \mathrm{e}\end{array}$ & $\begin{array}{r}16 \\
16 \\
16 \\
5 \\
15 \\
12 \\
12 \\
12 \\
12 \\
12 \\
17\end{array}$ & $\begin{array}{r}\text { S-6-59-7a } \\
7 \mathrm{~b} \\
7 \mathrm{c} \\
7 \mathrm{~d} \\
7 \mathrm{e} \\
7 \mathrm{f} \\
7 \mathrm{~g}\end{array}$ & $\begin{array}{r}8 \\
10 \\
10 \\
10 \\
10 \\
10 \\
10\end{array}$ & $\begin{array}{r}\text { S-8-59-1a } \\
1 \mathrm{~b} \\
1 \mathrm{c} \\
1 \mathrm{~d} \\
1 \mathrm{e} \\
\mathrm{S}-8-59-2 \\
\mathrm{~S}-8-59-7 \\
\mathrm{~S}-8-59-9 \mathrm{a} \\
9 \mathrm{~b} \\
\mathrm{~S}-8-59-10 \mathrm{a} \\
10 \mathrm{~b} \\
\mathrm{~S}-8-59-13 \mathrm{a} \\
13 \mathrm{~b} \\
13 \mathrm{c} \\
\mathrm{S}-8-59-14 \mathrm{a} \\
14 \mathrm{~b} \\
14 \mathrm{c} \\
14 \mathrm{~d} \\
14 \mathrm{e} \\
\mathrm{S}-8-59-18 \mathrm{a} \\
18 \mathrm{~b} \\
18 \mathrm{c} \\
18 \mathrm{~d} \\
18 \mathrm{e} \\
\text { S-8-59-21a } \\
21 \mathrm{~b} \\
21 \mathrm{c} \\
21 \mathrm{~d} \\
\text { S-8-59-22a }\end{array}$ & $\begin{array}{r}7 \\
7 \\
7 \\
9 \\
9 \\
13 \\
6 \\
3 \\
9 \\
9 \\
11 \\
8 \\
8 \\
10 \\
8 \\
11 \\
11 \\
11 \\
11 \\
8 \\
8 \\
10 \\
10 \\
10 \\
8 \\
8 \\
8 \\
11 \\
4 \\
6\end{array}$ & $\begin{array}{r}\text { S-8-59-19a } \\
19 \mathrm{~b} \\
19 \mathrm{c} \\
19 \mathrm{~d} \\
19 \mathrm{e} \\
19 \mathrm{f} \\
19 \mathrm{~g} \\
19 \mathrm{~h} \\
19 \mathrm{i}\end{array}$ & $\begin{array}{r}7 \\
7 \\
7 \\
7 \\
7 \\
9 \\
9 \\
9 \\
11\end{array}$ \\
\hline $\begin{array}{l}\text { Average } \\
\text { reaction } \\
\text { time }\end{array}$ & 13.2 & \multicolumn{2}{|c|}{9.7} & \multicolumn{2}{|c|}{8.6} & \multicolumn{2}{|c|}{8.1} \\
\hline $\begin{array}{l}\text { Total no. } \\
\text { specimens }\end{array}$ & 11 & \multicolumn{2}{|l|}{7} & \multicolumn{2}{|c|}{30} & \multicolumn{2}{|c|}{9} \\
\hline
\end{tabular}

from the same donor that had been used for the parent. The results are given in the third and fourth columns of Table II. The results for the progeny of singly grafted parents are tabulated separately from those for the progeny of the triply grafted parent. By comparing column one with columns three and four it can be seen that the reaction time for one- to three-day young from sensitized parents (average reaction time $=8.6$ and 8.1 days) is significantly shorter than that for young of comparable age from unsensitized parents (average reaction time $=13.2$ 
days). It can also be seen by comparing columns three and four that the parent with three successive grafts produced young with slightly greater sensitivity (average reaction time $=8.1$ days) than did the parents with a single graft (average reaction time $=8.6$ days). The evidence leaves little grounds for doubt that homograft sensitized parents can transfer this sensitivity to intra-ovarian young.

\section{Discussion}

These experiments indicate a basic similarity between adult $C$. aggregata and Carassius auratus (Hildemann, 1957b) concerning the homograft response. Both species reject homografts, and both can be sensitized by successive grafting. In both species the time for homograft rejection is shortened by increase in temperature. Barrymore (unpublished data) has made similar observations on adult swordtails (Xiphophorus helleri) as have Triplett and Barrymore (unpublished data) on Amphistichus argenteus and Hyperprosopon argenteum. Fin transplantations on xiphophorin fishes yield similar results (Kallman and Gordon, 1957). There is good reason to suspect that these phenomena could be observed in teleosts in general.

To the authors' knowledge only one publication to date has dealt with tissue transplantation in older embryonic or immature fishes. Humm et al. (1957) have transplanted melanomas from adult platyfish-swordtail hybrids to embryos of both species and their hybrids. These workers have found, in contrast to the present authors, that homografts on embryonic fishes will not survive. This difference in results could be explained in one or both of two ways. First, it should be noted that the tissues grafted by Humm and his colleagues were not normal and should not be expected to behave as such. The inability of the transplanted melanomas to survive could be interpreted as a physiological deficiency other than immunological incompatibility.

A second and more likely possible explanation must take into account the different developmental rates of platyfishes and swordtails as compared with $C$. aggregata. The young of the former two species become free-living in about three weeks (Hooper, 1943), whereas the latter spends about five months in the ovarian cavity of the parent. A close correlation has been noted between the time of parturition in mammals (e.g., Freund, 1930), hatching in birds (e.g., Murphy, 1914; Waterman, 1936) or metamorphosis in amphibians (Schwind, 1933, 1937; Triplett, 1958) and the development of the ability to react immunologically to implanted or injected foreign materials. If our interpretation of Humm's work is correct those animals that were not killed by mechanical blockage, resulting from a rapidly proliferating graft, retained the transplant until well after the normal time of birth. The present experiments show that in $C$. aggregata homograft incompatibility is expressed soon after birth. This is quite possibly also the case in xiphophorin fishes used by Humm et al.

There has been considerable speculation as to whether or not circulating antibody is responsible for tissue incompatibility (reviewed by Snell, 1957). The first clear proof of an immune reaction to homografts was published by Gorer (1937) who found that tumor homografts could elicit the formation of circulating antibodies capable of agglutinating donor red cells. More recent work (see Snell, 1957) has established that humoral antibodies are formed in a variety of species 
against a variety of transplanted tissues. Santos et al. (1959) have shown that the serum of graft-sensitized rodents, upon injection into other animals, can produce a passive heterograft sensitivity.

The present experiments on transfer of homograft sensitivity from parent to intra-ovarian embryos can be explained best by assuming that circulating antibody is produced against scale homografts. It is probable that antibody accumulates in the ovarian fluid and is ingested by the embryos (no placental connection exists). This hypothesized method of transfer is made more plausible by the fact that Hemmings and Morris (1959) have been able to observe the absorption of antibody from the gut in young mice. In addition, Brambel et al. (1959) have observed that homologous antitoxin is absorbed from the uterine cavity to the fetal circulation in the rabbit.

Hosoda et al. (1955) have reported experiments of interest in this context. They found that hens injected with horse erythrocytes produce antibodies and transfer these antibodies to offspring.

\section{SUMMARY}

1. Embryonic and adult Cymatogaster aggregata have been subjected to scale homotransplantations.

2. Homografts are rejected after a short period of time. The time required for graft rejection is temperature-dependent.

3. Increased sensitivity to homografts results from successive transplantations.

4. Intra-ovarian embryos used in these experiments were not capable of rejecting scale homografts.

5. Immature free-living fish rejected homografts, but more slowly than adults.

6. Pregnant females can transfer homograft sensitivity to intra-ovarian embryos. It is hypothesized that circulating antibody is passed to the embryo via the ovarian fluid and the embryonic hindgut.

\section{LITERATURE CITED}

Brambel, F. W. R., W. A. Hemmings and C. L. OAkley, 1959. The relative transmission of natural and pepsin-refined homologous antitoxin from the uterine cavity to the fetal circulation in the rabbit. Proc. Roy. Soc. London, Ser. B, 150: 312-317.

Cushing, J. E., 1942. An effect of temperature upon antibody-production in fish. J. Immun., 45: $123-126$.

Eigenmann, Carl H., 1889. On the development of California food fishes. Amer. Nat., 23: $107-110$.

FreUnd, J., 1930. Influence of age upon antibody production. J. Immun., 18: 315-324.

Goodrich, H. B., And Rowena Nichols, 1933. Scale transplantation in the goldfish, Carassius auratus. Biol. Bull., 65 : 253-265.

Gorer, P. A., 1937. The genetic and antigenic basis of tumor transplantation. J. Pathol. Bacteriol., 44 : 691-697.

Hemmings, W. A., And J. G. Morris, 1959. An attempt to affect the selective absorption of antibodies from the gut in young mice. Proc. Roy. Soc. London, Ser. B, 150: 403-409.

Hildemann, W. H., 1956. Scale homotransplantation in goldfish (Carassius auratus). Transpl. Bull., 3: 67-68.

Hildemann, W. H., 1957a. Early onset of the homograft reaction. Transpl. Bull., 3: 144-145.

Hildemann, W. H., 1957b. Scale homotransplantation in goldfish (Carassius auratus). Ann. New York Acad. Sci., 64: 775-791. 
Hooper, A. F., 1943. The early embryology of Platypoecilus maculatus. Copeia, 4: 218-224.

Hosoda, T., T. Kaneko, K. Mogi and T. Abe, 1955. Transfer of antibodies in the hen to her eggs and to the offspring. Bull. Natl. Inst. Agric. Sci. (Japan) Ser. G. Animal Husbandry, 10: 125-129.

Humm, D. G., E. E. Clark and J. H. Humm, 1957. Transplantation of melanophores from platy-swordtail hybrids into embryos of swordtails and platyfish and their hybrids. J. Exp. Biol., 34: 518-528.

Kallman, Klaus D., and Myron Gordon, 1957. Transplantation of fins in Xiphophorin fishes. Ann. New York Acad. Sci., 71: 305-320.

Medawar, P. B., 1946. Immunity to homologous grafted skin. I. The suppression of cell division in grafts transplanted to immunized animals. Brit. J. Exp. Path., 27 : 9-14.

Mori, Yasumasa, 1931. On the transformation of ordinary scales into lateral scales in the goldfish. J. Fac. Sci. Imp. Univ. Tokyo, 2: 185-194.

Murphy, J. B., 1914. Studies on tissue specificity. II. The ultimate fate of mammalian tissues implanted in the chick embryo. J. Exp. Med., 19: 181-186.

Santos, George W., Leonard J. Cole and Richard M. Garver, 1959. Antigenic stimuli for transplantation immunity to rat bone marrow heterografts in lethally $\mathrm{x}$-irradiated mice. J. Immunol., 83: 66-73.

Schwind, Joseph L., 1933. Tissue specificity at the time of metamorphosis in frog larvae. J. Exp. Zool., 66: 1-14.

Schwind, Joseph L., 1937. Tissue reactions after homoplastic and heteroplastic transplantation of eyes in the anuran amphibia. J. Exp. Zool., 77: 87-107.

Snell, C. D., 1957. The homograft reaction. Ann. Rev. Microbiol., 11: 439-458.

TARP, FRED H., 1952. A revision of the family Embiotocidae (the surfperches). Fish Bulletin No. 88, State of Calif. Dept. of Fish and Game, Bureau of Marine Fisheries. $1-99$.

Triplett, Edward L., 1958. The development of the sympathetic ganglia, sheath cells, and meninges in amphibians. J. Exp. Zool., 138: 283-312.

Waterman, A. J., 1936. Heteroplastic transplantation of embryonic tissues of rabbit and rat. Amer. J. Anat., 60: 1-25.

White, Phillip R., 1954. The Cultivation of Animal and Plant Cells. The Ronald Press Co., New York, p. 90. 


\section{$2 \mathrm{BHL}$ Biodiversity Heritage Library}

Triplett, Edward L and Barrymore, Susanne D. 1960. "Tissue specificity in embryonic and adult Cymatogaster aggregata studied by scale transplantation." The Biological bulletin 118, 463-471.

https://doi.org/10.2307/1538824.

View This Item Online: https://www.biodiversitylibrary.org/item/110976

DOI: https://doi.org/10.2307/1538824

Permalink: https://www.biodiversitylibrary.org/partpdf/2149

\section{Holding Institution}

Smithsonian Libraries

\section{Sponsored by}

Biodiversity Heritage Library

\section{Copyright \& Reuse}

Copyright Status: In copyright. Digitized with the permission of the rights holder.

License: http://creativecommons.org/licenses/by-nc-sa/3.0/

Rights: https://biodiversitylibrary.org/permissions

This document was created from content at the Biodiversity Heritage Library, the world's largest open access digital library for biodiversity literature and archives. Visit BHL at https://www.biodiversitylibrary.org. 